\title{
Test Variety Safflower Dye Krasa Stupinskaya in Contrasting Regions
}

\author{
Sulukhan Temirbekova ${ }^{1, *}$, Yuliya Afanasyeva ${ }^{2}$, Natalia Ionova ${ }^{3}$, Galina Metlina $^{4}$, Sergey Vasilchenko ${ }^{4}$, \\ Mastibek Norov ${ }^{5}$, Mukhtar Ashirbekov ${ }^{6}$, Sergey Konovalov², Veronica Bobkova ${ }^{2}$ \\ ${ }^{1}$ Federal State Budget Scientific Institution, All-Russian Research Institute of Phytopathology, Russia \\ ${ }^{2}$ Federal State Scientific Institution, All-Russia Selection- Technological Institute of Horticulture and Nursery, Russia \\ ${ }^{3}$ Department of Plant Physiology, Kazan (Volga) Federal University, Russia \\ ${ }^{4}$ Laboratory of All-Russian Research Institute of Crops name I.G. Kalinenko, Russia \\ ${ }^{5}$ Department of Agronomy, Agricultural University, Tadzhikistan \\ ${ }^{6}$ Kazakh National Agrarian University, Kazakhstan
}

Copyright $\bigcirc 2017$ by authors, all rights reserved. Authors agree that this article remains permanently open access under the terms of the Creative Commons Attribution License 4.0 International License

\begin{abstract}
As a result of many years of research produced a fundamental result from the access to the application result. As a result at the Center of the gene pool and bioresources of plants of Institute was created cultivar of safflower tinctorius named "Krasa Stupinskaya". Vegetation period from germination to maturity in the years with different meteorological conditions is 105-130 days. Duration of flowering is about a month. Stem is erect, branching, naked, height is about $83-90 \mathrm{~cm}$. Leaves are sessile, lanceolate, elliptic, with small spines. One plant can from 5-7 to 20-50 and more baskets. Seed's coat is hard, it is difficult to crack, reach $40-50 \%$ from the mass of seeds. The seeds do not fall off after their maturation. The weight of 1000 seeds - 48-51 g. Productivity in our zone is $0.8-1.0$ $\mathrm{t} / \mathrm{ha}$. Safflower seeds contain $32-38 \%$ of fat, the yield of oil - 240 liters $\mathrm{kg} / \mathrm{ha}$. Absolute fat content in the treated seeds reaches more than $60 \%$, and it is fit for food. Marked regularity reduces the cadmium content in seeds in relation to other plant organs. Cadmium contained in the seeds of 5-15 times smaller than in the leaves and 3-5 times lower than in the root. Displaying pronounced barrier properties of various plant organs varieties Krasa Stupinskaya relative to cadmium. Such a tendency is characteristic to a lesser degree for lead and zinc. The copper content in seeds is not lowered. Perhaps this is due to biogenic copper, which is required for normal growth and development of plants in minimal quantities. This cultivar does not affected by pests and diseases, except for enzyme-mycotic exhaustion of seeds (EMES). In wet years EMES causes seed's mass destruction by such diseases as Alternaria, Fusarium and others and as a result is a poor quality of seeds.
\end{abstract}

Keywords Abiotic, Biotic, Disease, Olive, Phytoremediation, Safflower, Variety

\section{Introduction}

N.I. Vavilov attached special importance to the issue of new cultures, fuller use of the world's wild flora both within in our country and abroad. Following his ideas, scientists learn and introduce in the production cultures, previously unknown in our agricultural science and practice. The problem of the new crops introduction is becoming increasingly important due to the fact that the provision of Russia by vegetable oils and biologically active substances is carried out mainly by imports. To such new cultures applies safflower [1]

Adaptive plant breeding aimed to harvest size and quality increasing by their better adaptation to the environment, including the ability to stand the effects of abiotic and biotic stressors. Therefore, global mobilization and adaptation of plant resources is the basis of the basis of progress in the more northern areas biologically possible and economically viable cultivation of new crops. Thanks to this were greatly expanded ranges of sunflower, corn, winter wheat, peas, rape, some types of fruit, berry and others cultures effective cultivation [2].

In recent years, world production of basic seed of oilseeds is a tendency to increase, due to increased demand for vegetable oils. Due to its high nutritional and dietary benefits, they are gradually replaced animal fats in the diet of people. The growing industry, especially in its modern industries aviation and space, there is a need for the use of oils with special properties, what have plant $[3,6]$.

In our opinion, safflower can serve as one of the promising crops, which will expand the range of cultivated oilseed crops in the Central area of the Non-chernozem zone [4].

In recent years in the US in a pilot plant in California selection operation performed on breeding varieties with a high content of oleic or linoleic acids. Obtained grades: Rio, Gila and Frio. [5]. 
Our study was the introduction of safflower in the contrasting regions, the study of its biological characteristics, and creation of adaptive varieties for using in agricultural production and food processing and the development of adaptive technology of cultivation recommendations.

Safflower (Carthamus tinctorius L.) belongs to the family Asteraceae. Homeland is Egypt, India. As a result of many years work (2005-2012 years) in All-Russia Selection-Technological Institute of Horticulture and Nursery (FGBNU VSTISP) was created a new safflower cultivar «Krasa Stupinskaya». Authors: Temirbekova S.K., Kulikov I.M., Kurilo A.A., Norov M.S. Metlina G.V., Postnikov D.A., Ionova N.E.

Krasa Stupinskaya is included in the State Register of Selection Achievements in the 2013, the patent № 6930. It is recommended for all regions of Russian Federation.

\section{Materials and Methods of Research}

The studies have been conducted in the Center of gene pool and Bioresources of plants FGBNU VSTISP, p. Mikhnevo, Stupinodistrict, Moscow region in 2005-2015, in 2012-2015 - in FGBNU the All-Russian Research Institute of grain crops Fano, Zernograd, Rostov Region and in the educational farm RSAU - MTAA or RSAU - MAA named after K.A. Timiryazev «Mummovskoe», Saratov region, and Central Tajikistan. The object of research was safflower cultivar Krasa Stupinskaya and collection samples from Tajikistan. Phenological observations and biometric assessment were conducted during the growing season in accordance with the Methodology of State testing of agricultural Cultures (1983). Harvest definition was carried out with using of sample plots in 3 replicates, accounting plot area $-10 \mathrm{~m}^{2}$. Determination of oil content in the seeds was conducted in accordance with GOST 10857 «Oilseeds». Determination of oil content, the fatty acid composition of the oil were made in accordance with GOST 30623-98 "Vegetable oils and margarine. Detection method of falsification».

\section{Agronomic Characteristics of Safflower Krasa Stupinskaya in Contrasting Soil and Climatic Conditions}

Comparative study of the growth zone influence on the vegetation period and the main economically valuable signs of safflower grown in four regions was made: Central Federal District (Moscow region, Mikhnevo), Volga Federal District (Saratov region) and the Southern Federal District (Rostov region) and Central Tajikistan.
Krasa Stupinskaya is an annual herbaceous plant with well-developed tap root system that penetrates into the soil to $10-20 \mathrm{~cm}$, in the southern regions up to $1.5-2 \mathrm{~m}$ (and Central Tajikistan). Stem is glabrous, erect, branchy, height is about $83-90 \mathrm{~cm}$. Leaves are sessile, lanceolate, oval or elliptical lancet, on the edges with small teeth, ending with small spines. The in florescence is many-baskets, $1.5-3.5 \mathrm{~cm}$ in diameter. The number of baskets on the plant increases from 5-7 to 20-50 pieces. The flowers are tubular, with five separate corolla yellow or orange color. Fruit - achene, brilliant, reminiscent of sunflower achenes. Its hard shell, it is difficult to split, is $40-50 \%$ of the seed weight. The seeds not crumble, can germinate at a temperature of $1-2{ }^{\circ} \mathrm{C}$, but there are better and friendly germinate when the soil warm up to $5-6^{\circ} \mathrm{C}$ and more at a depth of $10 \mathrm{~cm}$. Sowing in each region annually spent: in Mikhnevo - 7.05-11.05, in the Saratov region -7.05 , in the Rostov region -26.04 , in Central Tajikistan - 20.12-25.12 and 10.03-15.03 (spring planting). Seedlings always have been friendly and appeared in 3-8 days. Period from the beginning of budding until flowering was within 18-23 days. Flowering lasted about 29-35 days. Harvest ingathering was carried out in Mikhnevo - 23.08, in the Rostov region -12.08 , in the Saratov region - 16.08, In Central Tajikistan - 7.04-10.04 (at the winter sowing) and 28 June - 2 July (during the spring sowing). Vegetation period from germination to maturation was 96 days in Moscow region (versus 110-115 days in 2010-2012, 2014-2015), 93-95 days in the Rostov region and 89-103 days in the Saratov region and in Central Tajikistan 110 days. In all regions safflower vegetation period was almost the same (Table 1).

The calculation of basic safflower harvest indicators gave the following results: the number of plants per $1 \mathrm{~m}^{2}\left(\mathrm{p} / \mathrm{m}^{2}\right)$ was in Mikhnevo $-26 \mathrm{p} / \mathrm{m}^{2}$, in the Rostov region $-30 \mathrm{p} / \mathrm{m}^{2}$ (planted for seeds), in the Saratov region $-62 \mathrm{p} / \mathrm{m}^{2}$ (planted for feeding purposes). Plant height ranged from $63-80 \mathrm{~cm}$ in all regions. Weight of 1000 seeds and productivity are presented in Table 1. Mass of 1000 seeds were as follows: in Mikhnevo in $2010-50.0 \mathrm{~g} ; 2011-51.1 \mathrm{~g}, 2012-48.0 \mathrm{~g}$, $2013-30.3$ g, $2014-45.2$ g, $2015-44.7$ g; in the Saratov region in $2013-30.9 \mathrm{~g}, 2014-48.1 \mathrm{~g}, 2015-43.8 \mathrm{~g}$; in the Rostov region in $2012-42.3 \mathrm{~g}$, in $2013-53.4 \mathrm{~g}, 2014-42.6$ g, $2015-46.1$ g. In Moscow region productivity of safflower Krasa Stupinskaya was in $20130.4 \mathrm{t} / \mathrm{ha}$, in 2010-2012 - 0.8 t/ha, 2014-2015 - 0.8 t/ha; in Saratov region: $2013-0.9$ t/ha, $2014-2.0 \mathrm{t} / \mathrm{ha}$ and in the $2015-0.9 \mathrm{t} / \mathrm{ha}$; in Rostov region $1.25 \mathrm{t} / \mathrm{ha}$ in 2012 and $0.6 \mathrm{t} / \mathrm{ha}$ in $2013,2014-1.1 \mathrm{t} / \mathrm{ha}, 2015-$ $0.9 \mathrm{t} / \mathrm{ha}$. So the average yield of safflower in 2010-2015 was $0.7 \mathrm{t} / \mathrm{ha}$ in the Moscow region and $0.9 \mathrm{t} / \mathrm{ha}$ in the Rostov region, $1.2 \mathrm{t} / \mathrm{ha}$ in Saratov region and in the conditions of the Central Tajikistan $1.7 \mathrm{t} / \mathrm{ha}$ with an average weight of 1000 seeds $-34.3 \mathrm{~g}$. 
Table 1. Harvest indicators of safflower Krasa Stupinskaya for 2010-2015 in different regions

\begin{tabular}{|c|c|c|c|c|}
\hline & Cultivar & Weighof 1000 seeds, $g$ & Productivity, $\mathrm{t} / \mathrm{ha}$ & Vegetative period, days \\
\hline \multicolumn{5}{|c|}{ Environmental study in Moscow region } \\
\hline 1 & Krasa Stupinskaya, 2010 & 50,0 & 0,9 & 112 \\
\hline 2 & Krasa Stupinskaya, 2011 & 51,1 & 0,8 & 115 \\
\hline 3 & Krasa Stupinskaya, 2012 & 48,0 & 0,7 & 115 \\
\hline 4 & Krasa Stupinskaya, 2013 (antypical wet year) & 30,3 & 0,4 & 96 \\
\hline 5 & Krasa Stupinskaya, 2014 & 45.2 & 0.8 & 113 \\
\hline \multirow[t]{2}{*}{6} & Krasa Stupinskaya, 2015 & 44.7 & 0.8 & 105 \\
\hline & Averages & 44.8 & 0.7 & 109 \\
\hline \multicolumn{5}{|c|}{ Environmental study in Rostov region } \\
\hline 7 & Krasa Stupinskaya, 2012 & 42,3 & 1,25 & 93 \\
\hline 8 & Krasa Stupinskaya, 2013 & 53,4 & 0,63 & 95 \\
\hline 9 & Krasa Stupinskaya, 2014 & 42.6 & 1.1 & 95 \\
\hline \multirow[t]{2}{*}{10} & Krasa Stupinskaya, 2015 & 46.1 & 0.9 & 94 \\
\hline & Averages & 46.1 & 0.9 & 94 \\
\hline \multicolumn{5}{|c|}{ Environmental study in Saratov region } \\
\hline 11 & Krasa Stupinskaya, 2013 & 30,9 & 0,9 & 94 \\
\hline 12 & Krasa Stupinskaya, 2014 & 48.1 & 2.0 & 103 \\
\hline \multirow[t]{3}{*}{13} & Krasa Stupinskaya, 2015 & 43.8 & 0.9 & 89 \\
\hline & Averages & 40.9 & 1.2 & 95 \\
\hline & \multicolumn{4}{|c|}{ Environmental testing in Central Tajikistan } \\
\hline 14 & Krasa Stupinskaya, 2014 & 34,2 & 1,7 & 109 \\
\hline \multirow[t]{3}{*}{15} & Krasa Stupinskaya, 2015 & 34,5 & 1,8 & 111 \\
\hline & Averages & 34,3 & 1,7 & 110 \\
\hline & $\mathrm{NSR}_{05}$ & 0,7 & 0,1 & \\
\hline
\end{tabular}

Krasa Stupinskaya is recommended as sidereal, phytosanitary, fodder, ornamental and promising oilseed culture. Best of all as a green manure safflower manifests itself on sod-podzolic soils.

Green manure crops (so-called green manure) are an important source of organic matter replenishment in soils. For example, white mustard sown in hectare of land - is the same that make it 20 tons of manure for one season, on 1 hectare lupins can save up to $160 \mathrm{~kg}$ of nitrogen, which is equivalent to 30-35 tons of manure [7]. Green manure is really conducive to the rapid enrichment of soil organic matter, reduces its acidity and reduces content of mobile aluminum, increase microbiological activity. In addition using green fertilizers tissue and fruit plants are not contaminated by chemicals (fertilizers and pesticides).

Traditional green manure crops: white mustard, blue lupine, winter rye etc. However, there is a special culture safflower that has a number of unique properties for the Moscow region conditions.

Green manure crops have a diversified impact on the nutrient status of soddy-podzolic soil. Plowing under the white mustard post-cut root residues provides involvement optimization of the accumulated nitrogen into the circulation in the topsoil after the decomposition of root residues. Phosphorus accumulation in the root mass of the white mustard is $0.7 \%$ but due to the small mass of the roots their effect on the content of phosphorus in the soil is insignificant. Decomposition rate of the white mustard post-cut root residues decelerates in response to the separation of monocarboxylic acid in plant roots, and, probably, there is no complete decomposition of white mustard root mass at the time of soil samplings [8,9].

Potassium content in the soil after burial of the white mustard post-cut root residues increases as compared with the control by $1 \%$. As a result of burial of the total white mustard plant mass, soil nitrogen is back into the soil up to $40 \mathrm{~kg} / \mathrm{ha}$. As for phosphorus, its value is to $20 \mathrm{~kg} / \mathrm{ha}$.

In the context of complete green manuring of blue lupine, soil nitrogen is back into the soil up to $140 \mathrm{~kg}$, allowing keeping a positive balance of this element after harvesting the major crop. The positive dynamics of the content of available phosphorus is in the topsoil should be noted [10].

In a view of plowing the safflower post-cut root residues, nitrogen re-entry in the soil can be up to $8.5 \mathrm{~kg}$, and during burial of the whole green mass from the root mass to the aboveground part, $120 \mathrm{~kg} / \mathrm{ha}$ of biological nitrogen returns in 
the soil in total, that is relatively similar to the blue lupine on average. In terms of $\mathrm{P}_{2} \mathrm{O}_{5}$, plowing of safflower green mass corresponds to an average returns to the soil up to $40 \mathrm{~kg} / \mathrm{ha}$. Plowing of safflower at flowering stage has a positive effect on the exchange potassium content in the root layer of the soil.

The yields of dry aboveground part of safflower in different years were as follows: from 9.1 to $9.97 \mathrm{t} / \mathrm{ha}$, and the root part - from 1.30 to $1.60 \mathrm{t} / \mathrm{ha}$.

In general, while analyzing the values obtained by the effect and aftereffect of green manuring on contents of basic food elements in the soil, it is important to emphasize that this technique should be considered in complex with other agrochemical techniques for making compost, fertilizers and meliorates.

The white mustard usage as a green manure is of interest to those crop rotations, where the crop is used as between crop and sown in early spring before planting potatoes or autumn after harvesting of the major crop. Under conditions of the southern part of Moscow region, effective tool for enhancing the activity of the soil microflora and increasing the isolated circulation of substances in agrocenoses is burial, which in turn should be used along with the traditional cultures and with introduced plant-culture - safflower [9].

We have considered various application schemes of examined green manure crops and revealed that in the case of white mustard full green manuring is optimal in the context of the agronomy, and in case of growing lupine and safflower green material can be used for feeding purposes. In the absence of livestock specialization, farms should carry out full burial of aboveground mass of green manure crops, which provide indicators improving of effective soil fertility.

In modern agricultural systems, green manuring should not base on the only one culture, because the functional integrity of the intensive agroecosystems is defined by the set of cultivated species, which may belong to different families and thus have diverse effects on agrocoenosis generally. Expanding of the green manure crop range creates the right conditions for further domestic agricultural greening, for the integrated and sustainable development of the agricultural sphere in whole [10].

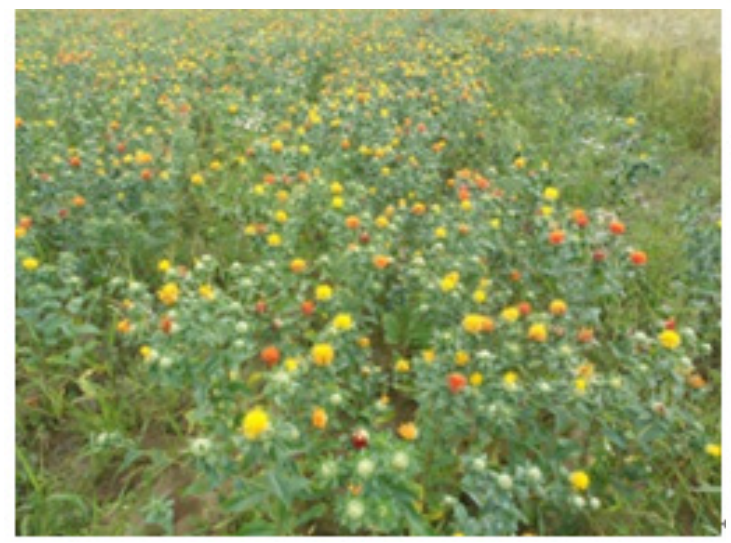

\section{Safflower Phytosanitary Role}

Safflower cultivation for green manure reduces contamination subsequent cereal - spring barley up to 24 $\mathrm{pcs} / \mathrm{m}^{2}$ or $62 \%(2008-2009)$, Spelled $-11 \mathrm{pcs} / \mathrm{m}^{2}$ or $89 \%$ (2013-2014) after two years of safflower growing. Infestation in barley and spelled crops after mustard white and blue lupine averaged was $17-20 \mathrm{pcs} / \mathrm{m}^{2}$ or $20.2 \%$.

\section{Safflower as an Oilseed}

At the moment seeds oil content increasing selection has become a major asset of our agricultural production, such as the property becomes a breeding for oil quality change.

It has been shown that each variety and even the shape of the population are composed of a larger or smaller number of biotypes differing by number of features, including the concentration of the fatty acid oil [11].

The basis in the selection to the quality of oil for technical and food use is the knowledge of genotypic variability of the fatty acids composition in the range of cultivated species and wild relatives. N.I. Vavilov attached great importance to the study of differentiation within the species for chemical signs of quality grades [12] repeatedly emphasizing need to identify genetic differences that can be seen in the study in the same conditions of different varieties in different geographical locations.

It was observed that linoleic acid in sunflower oil contains near $67 \%$, and in safflower oil - $80 \%$ under the experimental conditions of VIR Kuban station.

Qualitative differences are determined by genetic characteristics of oil varieties and forms. Oils quality features can be enhanced by content increasing of main fatty acids (oleic and linoleic).

Large variability in the content of linoleic acid in the various years of cultivation is probably due to a stretched period of flowering and late maturing of certain cultures. Fluctuations in temperature cause changes in the partial pressure of oxygen in the cells, which affects the processes of oxidative hydrogenation.

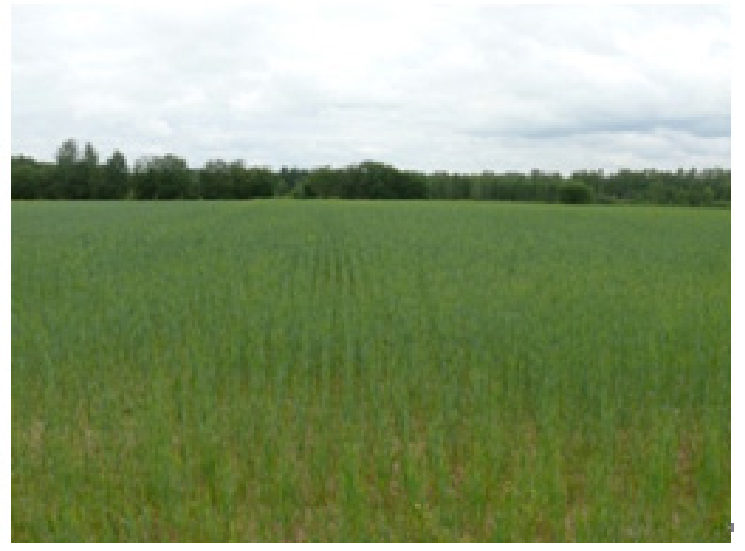

Figure 1. Safflower crops (left) and his effects on the subsequent culture spelled in 2014 (right). 
It has been determined the influence of environmental on the unsaturated fatty acids accumulation rate - oleic and linoleic. In all sunflower varieties intensive accumulation of linoleic acid observed in more northern growing area compared with the southern zone (71.7-72.0 and 53.7-59.0\%, respectively). Thus high linoleic acid content combined with a low concentration of oleic (16.9-17.9 and 29.0-36.0\%, respectively).

The oils of different crops include fatty acids, mainly with $\mathrm{C}_{16}$ to $\mathrm{C}_{22}$ chains, saturated or unsaturated with double bonds (one, two, and three). Within various crop species identified individual grades and within individual varieties biotypes differing by increased or reduced content of typical fatty acids. These biotypes features caused by various factors (mutation, etc.) are also inherited. Individual variability (for plants) is the basis of selection to increasing of concentrations and a decrease in some - other fatty acids, functionally related to each other.

A comparative analysis of the seeds oil content of safflower Krasa Stupinskaya for three years, grown in Moscow and Rostov regions showed that the content of the seeds mass fraction of fat in Rostov region (2013) was $19.02 \%$, which is $4.42 \%$ higher than in 2012, in 2014 $23.7 \%$, which is $9.2 \%$ higher than the seeds oil content in 2012. The oil content in the seeds grown in the Moscow region in 2012 showed $-22.92 \%$, which is $8.42 \%$ higher than in the Rostov region. In atypical weather conditions in 2013 seeds oil content of safflower grown in the Rostov region was $12.66 \%$ higher than that in safflower grown in the Moscow region - 6.4\%. In 2014, safflower seed oil content in the Moscow region amounted to $30.2 \%$, which is $6.5 \%$ higher than in safflower from the Rostov region $(23.7 \%)$

\section{(Table 2).}

Perhaps the formation of oil content in the Moscow region was influenced by the temperature factor $-16.4{ }^{\circ} \mathrm{C}$ against $18.6^{\circ} \mathrm{C}$ in the Rostov region, the number of precipitation regions is not particularly different (190.7 and $184.1 \mathrm{~mm}$, respectively).

It should be noted a direct correlation between the fat content in the seeds of safflower and the amount of precipitation during the growing season and temperature.

Table 3 shows the influence of agro-biological factors on the oil content of seeds safflower cultivation in contrasting years. The analysis of the seed oil content at 5 reproductions years (2010-2015) safflower cultivar Krasa Stupinskaya grown in the Moscow region is shown in Table 3. In 2010, the acutely arid, characterized by high air temperature $18.8^{\circ} \mathrm{C}$ (long-term average $-15,1^{\circ} \mathrm{C}$ ) and low precipitation $154.4 \mathrm{~mm}$ during the growing season, the accumulation of a mass fraction of fat in the seeds was $-31.2 \%$ and in a more humid $2011-285.5 \mathrm{~mm}$ rainfall during the growing season, temperature $17.8^{\circ} \mathrm{C}$ in 2012 (optimal warmth, less humid) $245.8 \mathrm{~mm}$ during the growing season, temperature $17.8^{\circ} \mathrm{C}$ was respectively 29.0 and $22.3 \%$. In 2013 , when the rainfall during the growing season fell to $335.8 \mathrm{~mm}$ (at a rate of 264 $\mathrm{mm}$ ) and a temperature of $18.4{ }^{\circ} \mathrm{C}$, the mass fraction of fat was only $6.4 \%$, in 2014 precipitation during the growing season was $184.1 \mathrm{~mm}$, average temperature $-16,4^{\circ} \mathrm{C}$, oil content was $30.2 \%$, in 2015 - 30,9\%(348,4 $\mathrm{mm}$ and a temperature $-18,9^{\circ} \mathrm{C}$ ) in variety Krasa Stupinskaya. In 2015 , oil content of seeds varieties Krasa Stupinskaya was 34.3\% in the Central Tajikistan and in the Central region of the Russian Federation - 30.9\%.

Table 2. Comparative characteristics of safflower oil percentage, 2012-2014

\begin{tabular}{|c|c|c|c|c|c|c|}
\hline \multirow[b]{2}{*}{ Nameofindicator } & \multicolumn{6}{|c|}{ Variety } \\
\hline & $\begin{array}{c}\text { Krasa } \\
\text { Stupinskaya, } \\
\text { Rostovregion, } \\
2012 \\
\end{array}$ & $\begin{array}{c}\text { Krasa } \\
\text { Stupinskaya, } \\
\text { Rostovregion, } \\
2013 \\
\end{array}$ & $\begin{array}{c}\text { Krasa } \\
\text { Stupinskaya, } \\
\text { Rostovregion, } \\
2014 \\
\end{array}$ & $\begin{array}{c}\text { Krasa } \\
\text { Stupinskaya, } \\
\text { Moscowregion, } \\
2012\end{array}$ & $\begin{array}{c}\text { Krasa } \\
\text { Stupinskaya, } \\
\text { Moscowregion, } \\
2013\end{array}$ & $\begin{array}{c}\text { Krasa } \\
\text { Stupinskaya, } \\
\text { Moscowregion, } \\
2014\end{array}$ \\
\hline $\begin{array}{l}\text { Oil content (fat mass } \\
\text { fraction), } \%\end{array}$ & 14.5 & 19.02 & 23.7 & 22.92 & 6.4 & 30.2 \\
\hline
\end{tabular}

Table 3. The influence of agro-biological factors on seed's oil in contrasting years, 2010-2014

\begin{tabular}{|c|c|c|c|c|c|c|}
\hline \multirow[b]{2}{*}{ № } & \multirow[b]{2}{*}{ Sample } & \multirow{2}{*}{$\begin{array}{l}\text { Oil content (fat mass } \\
\text { fraction), } \%\end{array}$} & \multicolumn{2}{|c|}{ Precipitation, $\mathrm{mm}$} & \multicolumn{2}{|c|}{ Temperature, $\mathrm{t}^{0} \mathrm{C}$} \\
\hline & & & $\begin{array}{l}\text { Average during } \\
\text { several years }\end{array}$ & $\begin{array}{l}\text { Average during the } \\
\text { growing season }\end{array}$ & $\begin{array}{l}\text { Average during } \\
\text { several years }\end{array}$ & $\begin{array}{c}\text { Average during the } \\
\text { growing season }\end{array}$ \\
\hline 1 & $\begin{array}{c}\text { Krasa Stupinskaya } \\
\text { Moscow region, } 2010 \text { г. }\end{array}$ & 31.2 & 264 & 154.4 & 15.1 & 18.8 \\
\hline 2 & $\begin{array}{l}\text { Krasa Stupinskaya } \\
\text { Moscow region, } 2011\end{array}$ & 29.0 & 264 & 285.5 & 15.1 & 17.8 \\
\hline 3 & $\begin{array}{c}\text { Krasa Stupinskaya } \\
\text { Moscow region, } 2012\end{array}$ & 22.3 & 264 & 245.8 & 15.1 & 17.8 \\
\hline 4 & $\begin{array}{c}\text { Krasa Stupinskaya } \\
\text { Moscow region, } 2013\end{array}$ & 6.4 & 264 & 335.8 & 15.1 & 18.4 \\
\hline 5 & $\begin{array}{c}\text { Krasa Stupinskaya } \\
\text { Moscow region, } 2014\end{array}$ & 30.2 & 264 & 184.1 & 15.1 & 16.4 \\
\hline 6 & $\begin{array}{c}\text { Krasa Stupinskaya } \\
\text { Moscow region, } 2015\end{array}$ & 30.9 & 264 & 348,4 & 15,1 & 18,9 \\
\hline
\end{tabular}


Table 4. Fatty acid composition of safflower oil in 2013-2014

\begin{tabular}{|c|c|c|c|c|}
\hline \multirow{2}{*}{ Fattyacids } & \multicolumn{4}{|c|}{ Mass fraction of fatty acids, \% to total content of fatty acids } \\
\cline { 2 - 5 } & Mahalli260(Tajikistan), 2013 & Krasa Stupinskaya, 2013 & Krasa Stupinskaya, 2014 & $\begin{array}{c}\text { Norms in accordance } \\
\text { with GOST30623-98 }\end{array}$ \\
\hline $\mathrm{C}_{14: 0}$ (myristic) & 0,1 & 0,1 & 0,1 & $<1,0$ \\
\hline $\mathrm{C}_{16: 0}$ (palmitic) & 7,6 & 7,7 & 9.94 & $2,0-10,0$ \\
\hline $\mathrm{C}_{16: 1}$ (palmitoleic) & 0,2 & 0,1 & 0,55 & $<0,5$ \\
\hline $\mathrm{C}_{18: 0}$ (stearic) & 2,6 & 2,0 & 2,48 & $1,0-10,0$ \\
\hline $\mathrm{C}_{18: 1}$ (oleic) & 13,2 & 13,6 & 16,89 & $7,0-42,0$ \\
\hline $\mathrm{C}_{18: 2}$ (linoleic) & 75,6 & 75,7 & 65,88 & $55,0-81,0$ \\
\hline $\mathrm{C}_{18: 3}$ (linolenic) & 0,2 & 0,1 & - & $<1,0$ \\
\hline $\mathrm{C}_{20: 0}$ (arachidic) & 0,3 & 0,4 & - & $<0,5$ \\
\hline $\mathrm{C}_{20: 1}$ (gondoinovaya) & 0,2 & 0,3 & - & $<0,5$ \\
\hline
\end{tabular}

In samples Moldir - 24.0\%, Moldir $2008-22.2 \%$ and VIR $2933-21.7 \%$, respectively $[13,14]$

It is important the creation of breeding varieties with different fatty acids ratio in the oil, table. 4 .

According to the content of linoleic acid that is not synthesized in the human body, this variety (Krasa Stupinskaya) is not inferior to the southern variety Mahalli 260. According to the content of oleic acid - $16.89 \%$, responsible for preserving the freshness of the oil over a long period, it exceeded other varieties. The higher content of saturated fatty acids, particularly palmitic characterized sort Krasa Stupinskaya. Krasa Stupinskaya has oil yield near 240 $\mathrm{kg} / \mathrm{ha}$ (at plant density of 250-300 thousand/ha and seed yield $-0.8 \mathrm{t} / \mathrm{ha}$ ). In Central Tajikistan oil output amounted near $940 \mathrm{~kg}$ per hectare (at plant density of 160 thousand plants per hectare and crop seeds $1.7 \mathrm{t} / \mathrm{ha}$ ).

The productivity increase and safflower product quality depends on farming practices of cultivation. It is necessary to adhere to morph biological features of crops and varieties, keeping the complex soil-climatic conditions of the region, a specific agricultural production, hydrothermal regime during the growing season. What matters is technical equipment, financial condition and agronomic management frames.

Therefore, the potential yield and economic effect of the new culture introduction will largely depend on the use cultivation technology adapted to local conditions, taking into account all these factors. All agricultural practices that are recommended for the cultivation of crops should be carried out at one time, because the omission or wrong application of one of the elements will affect the yield and quality of seeds.

\section{Accumulation of Heavy Metal Culture of Safflower}

We have carried out studies on the effectiveness of phytoremediation of soils, which is determined by the parameters of the relationship in the soil-plant (with seeds on depth of 3,5,7 cm) heavy metal accumulation factor of culture safflower cultivar Krasa Stupinskaya, resistant culture to contamination, biological yield on contaminated soil depth of the main mass of roots dissemination and uptake of heavy metals from different layers of the soil profile. For oilseed crops in the Russian Federation the limit allowable concentration of heavy metals is not accepted. However, the content of heavy metals in plant organs: root, stem, leaves and high regularity observed decrease cadmium content in the seeds of safflower in relation to other plant organs. Cadmium contained in the seeds of 15 times less than in the leaves and 3-5 times lower than in the root. This demonstrates the pronounced barrier properties of various organs grades Krasa Stupinskaya with respect to cadmium. To lead and zinc are also characterized by this trend, but to a lesser degree. The copper content in the seeds in relation to other organs of plants not naturally decreases, which shows the absence of any barrier properties of safflower towards heavy metal present. This fact is probably due to biogenic copper, which in small amounts is essential for normal growth and development of plants (table 5).

Table 5. The content of heavy metals in plants organs safflower variety Krasa Stupinskaya, Mikhnevo, Moscow region, 2015

\begin{tabular}{|c|c|c|c|c|c|}
\hline \multirow{2}{*}{ Variety } & \multirow{2}{*}{$\begin{array}{l}\text { Plants } \\
\text { organ }\end{array}$} & $\mathrm{Cd}$ & $\mathrm{Pb}$ & $\mathrm{Cu}$ & $\mathrm{Zn}$ \\
\hline & & $\mathrm{mg} / \mathrm{kg}$ & $\mathrm{mg} / \mathrm{kg}$ & $\mathrm{mg} / \mathrm{kg}$ & $\mathrm{mg} / \mathrm{kg}$ \\
\hline \multirow{4}{*}{$\begin{array}{l}\text { Krasa Stupinskaya } \\
3 \mathrm{~cm} \text { sowing depth }\end{array}$} & Leaves & 0.53 & 0.65 & 3.82 & 8.27 \\
\hline & Seed & 0.11 & 0.58 & 5.39 & 2.27 \\
\hline & Root & 0.50 & 0.67 & 3.52 & 8.42 \\
\hline & Stem & 0.37 & 0.25 & 2.58 & 4.05 \\
\hline \multirow{4}{*}{$\begin{array}{l}\text { Krasa Stupinskaya } \\
5 \mathrm{~cm} \text { sowing depth }\end{array}$} & Leaves & 1.19 & 0.37 & 7.26 & 46.5 \\
\hline & Seed & 0.08 & 0.60 & 5.50 & 18.58 \\
\hline & Root & 0.29 & 0.25 & 3.71 & 7.43 \\
\hline & Stem & 0.24 & 4.29 & 7.71 & 9.29 \\
\hline \multirow{4}{*}{$\begin{array}{l}\text { Krasa Stupinskaya } \\
7 \mathrm{~cm} \text { sowing depth }\end{array}$} & Leaves & 0.81 & 0.63 & 4.01 & 10.66 \\
\hline & Seed & 0.15 & 0.63 & 5.29 & 7.92 \\
\hline & Root & 0.45 & 0.31 & 5.81 & 7.82 \\
\hline & Stem & 0.20 & 0.13 & 1.61 & 2.02 \\
\hline \multicolumn{2}{|c|}{$\begin{array}{c}\text { The limit allowable } \\
\text { concentration of heavy metals } \\
\text { in food raw materials and food } \\
\text { products (SanPiN } \\
42-123-4089-86 \text { from } \\
31 / 03 / 86, \text { the) (seed) }\end{array}$} & 0.03 & 0.3 & 10.0 & 50.0 \\
\hline
\end{tabular}




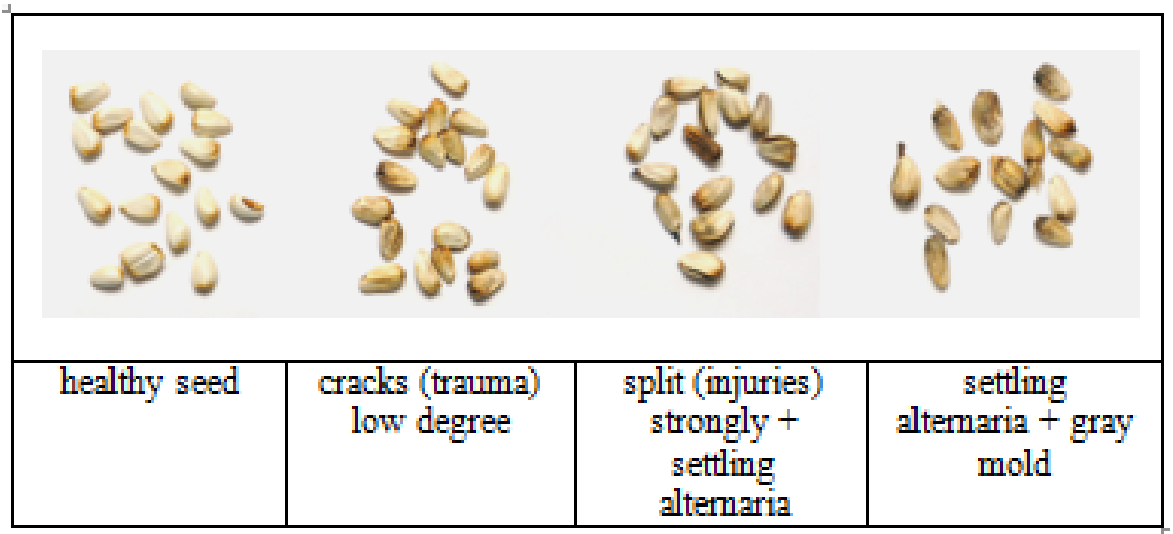

Figure 2. The development of enzyme and mycotic stage of enzyme-mycotic exhaustion of seeds (EMIS)

\section{Protecting Plants from Pests and Diseases}

Protecting plants from pests and diseases: Seed treatment mandatory agricultural practices to protect against pests of safflower. It is conducted 1-3 months before planting using Vintsitom 10 l/t seeds or Maxim - $5 \mathrm{~kg} / \mathrm{t}$, or you can use other modern drugs approved for use. Upon reaching on crops culture safflower critical number of insects is necessary to apply insecticides: Karate - 0.3 1/ha, Kinmiks - 0.15 1/ha. It should be noted that in wet years sort Krasa Stupinskaya strongly affected enzyme-mycotic exhaustion seeds (EMIS) [15]. Enzyme stage EMIS, namely, biological injury on the vine in the phase of seeds forming causes cracking of the seed coat, the introduction of plant pathogens and promotes mass seed destruction by Alternaria, Fusarium, Botrytis and Sclerotinia, and, eventually, poor quality seeds.

Pest safflower can be wireworms and cutworms and other specific pests - Sage scoop and safflower fly. At the moment, they are absent in the Central region. On safflower homeland encountered diseases: rust, ramulyarioz (disease manifests itself in the form of spotting on leaves, yellow-brown spots or brown with dark borders, rounded). Ryamulyarioz occur singly, not in all the years of cultivation and special harmfulness of the variety does not cause. Rust is not yet available in the Central and North Caucasus regions.

In conclusion, it should be noted that in India, which in the first position on safflower in the world, special attention is not on the collection of seeds per hectare, and the collection of safflower flowers. Collection of flowers is a cost-effective, profitable for farmers, as they are traditionally used in India not only for dyeing, but also as a food dye. Recently it became known about the use of colors safflower in China and Kazakhstan as an herbal medicine for the treatment of several chronic diseases, such as hypertension, coronary heart disease and stroke. Therefore, honey, and flowers of safflower culture are of special value for human health.

\section{Conclusions}

1. The vegetation period from full germination to full maturity safflower culture in the Central Federal District in an excessively wet, atypical in 2013 was 96 days, 2010-2012, 2014 research - 114 and in 2015 - 105 days, average for 5 years - 111 days, in the Southern federal District - 94 days, in the Volga federal District - 95 days in the Central Tajikistan 110 days (the average for all years of study).

2. Safflower plant height in all regions ranged from 63.1 to $70.8 \mathrm{~cm}$. Weight of 1000 seeds in different years was 30.3-53.4 g of crop seeds, safflower variety Krasa Stupinskaya per 1 ha Moscow region for 2010-2015 amounted to $-0.7 \mathrm{t} / \mathrm{ha}$, in the Rostov region for the 2012-2015 biennium - 0.9 t/ha, in the Central Tajikistan - 1.7 $\mathrm{t} / \mathrm{ha}$ (based on the seed purposes) and in the Saratov region for 2013-2015 years - 1.2 t/ha (based on feed purposes).

3 . In all regions, noted a sufficient accumulation of oil content in favorable on agrometeorological conditions during filling and maturation of seeds. The greatest accumulation of fat mass fraction (in terms of dry matter) in the seeds of safflower dye varieties Krasa Stupinskaya (Moscow region in reproduction) noted in the harvest 2010, 2011 and 2012 from 22.3 to $31.2 \%$ (with the exception of 2013 - 6.4\%). In the Rostov region, it was from 14.5 to $23.7 \%$ and $-34.3 \%$ in Central Tajikistan. According to the content of linoleic and oleic acid variety released Krasa Stupinskaya, which is important for practical purposes.

4. In wet years, the flowering and ripening of safflower of the progression of the disease observed enzymatic step enzyme-mycotic exhaustion of seeds - biological injury on the top followed by the defeat of baskets and seeds with phytopathogen Alternaria carthami Ch. and Botrytis cinerea Pers.

5. The content of heavy metals in plant organs: root, stem, leaves and high regularity observed decrease cadmium content in the seeds of safflower in relation to other plant organs.

\section{REFERENCES}

[1] Gorbatenko L.E., Ozerskaya T.M., Stishonkova N.A. N.I. Vavilov - the creator of the introduction of the theory of world 
collection of VIR. The genetic resources of cultivated plants in the XXI century. Condition, Problems and Prospects. Vavilov II International Conference (26-30 November 2017). C.-P. - 2007. - P. 15-17.

[2] Zhuchenko A.A. Adaptive strategy for sustainable development of the Russian agriculture in the XXI century. Theory and practice. In two volumes. - M.: Agrorus, 2009-2011. - T. I. The - 415 p.

[3] Nechiporenko V.N. The state and the factors increasing the production of flax seed, castor, sesame, peanuts. - M., 1990. $58 \mathrm{p}$.

[4] Kurilo A.A., Postnikov D.A., Temirbekova S.K. Safflower under the Moscow region. Cultivated plants for sustainable agriculture in the XXI century (immunity, selection, and introduction). Scientific works. - T. IV.- 4.2 M : Rosselkhozakademia. - 2011 - to 218-222

[5] Vedmedeva, E., Lebed H., Aksenov I. Secrets of safflower. "Grain" magazine. - 2006. - p. 34-37.

[6] Norov M.S. Technology of cultivation of safflower in conditions of bogary of the Republic of Tajikistan (recommendation). Dushanbe "Infon", 2009, 38 p.

[7] Prianishnikov D.N. Selected Compositions. M .: - 1965. - T. 2. - P. 379-395.

[8] Postnikov D.A., Temirbekova S.K., Loshakov V.G. et al. Comparison agroekological evaluation of the use of traditional and emerging green manure crops in the Moscow Region / D.A. Postnikov, S.K. Temirbekova, V.G. Loshakov // Advances in science and machinery technician agriculture. M.: 2014 № 8, pp 39-43.

[9] Temirbekova S.K. Using the new introduced species - safflower under the conditions of the Central region of non-chernozem zone of Russia. // Temirbekova S.K., Kurilo A.A., Afanasyeva Y.V., Konovalov S.N / Kormoproizvodstvo. № 6. 2015. - p. 24-28.

[10] Kurilo A.A., Temirbekova S.K. Phytomeliorative influence of white mustard, blue lupine and safflower to effective fertility of sod-podzolic soils / A.A. Kurilo, S.K. Temirbekova // Fruit and berry-culture of Russia. - 2010. - T. XXIII. - P. 275-282.

[11] Ermakov A.I., Popova E.V. Sunflower breeding for improving the technological properties of food and oil.Works of applied botany, genetics and breeding. - T. 48 - 1972 - Vol. 3. - P. 171-172.

[12] Vavilov N.I. Selection as a science. // Selected Works / Leningrad. 1967. Vol.1. - P. 328-343.

[13] Temirbekova S.K. Introduction and features of cultivation of safflower seeds in the conditions of the Central area of the Non-chernozem zone / S.K. Temirbekova, I.M. Kulikov, N.E. Ionova et al. // Herald of the Russian Academy of Agricultural Sciences. - 2014. - №1. - P. 41-43.

[14] Temirbekova S.K. The role of adaptive potential in enhancing the environmental sustainability of safflower in the three regions of the Russian Federation // S.K. Temirbekova, I.M. Kulikov, G.V. Metlina, Y. Afanasiev, S.A. Vasilchenko, N.E. Ionova / Education, science and production. Orel. №4, 2014. P. 21-25.

[15] Temirbekova S.K. Biological injury crops standing in the light of the law of homologous series in hereditary variation of N.I.Vavilov // Temirbekova S.K., Alimov K.G., Popova E.V., Gromova B. B.-O., Nikolenko V.F., Maximov A.V. / Cultivated plants for sustainable agriculture in the XXI century. Volume 3.For the 120th anniversary of Academician N.I. Vavilov. - M. - RAAS, 2008 - P. 175-193. 